\title{
Analysis of Environmental Impact for Residential Building in Singrauli District of (M. P.)
}

\author{
${ }^{1}$ Dr. Vinod Dubey, ${ }^{2}$ Mrs. Pratibha Bhargava, ${ }^{3}$ Miss Aparna Pandey, \\ ${ }^{4}$ Pramod Kumar Singh \\ ${ }^{l}$ Professor of Chemistry, S. G. S. Govt. Auto. P. G. College, Sidhi (M.P.) \\ ${ }^{2,3}$ Research Scholar at Depatt. of Chemistry, S. G. S. Govt. Auto. P. G. College, Sidhi (M.P.) \\ ${ }^{4}$ Research Scholar Geography, at S. G. S. Govt. Auto. P. G. College, Sidhi (M.P.)
}

\begin{abstract}
The finding of this research work highlights the environmental impact of a building from its construction phase to the end of its life i.e. demolition. Where we have only considered the emission of CO2 responsible for environmental issues.

As the global warming is most serious issue for environment. we are very much concern about the emission of $\mathrm{CO} 2$ from different industries, However emission from a building for its entire life cycle is seldom taken seriously. Since there are huge number of building already exist and number of buildings are being under construction in and around Singrauli district which are well known for its. coalmines and coal based industries like NTPC's. Hence if possible, any reduction in $\mathrm{CO} 2$ emission will make a great contribution to reduce overall $\mathrm{CO} 2$ emission and it could be achieved by using stone in place of bricks chips as a buildings material as the result obtained through Analysis, reveals the same.

This research paper categorically estimates the $\mathrm{CO} 2$ emission from various building plans for its entire life, which hopefully guide us for reducing $\mathrm{CO} 2$ emission. Two multistoried residential buildings in Singrauli have been analyzed one with stone and another with bricks of same area of construction for assessing environmental impact considering their 60 years life time.
\end{abstract}

Key words: Environment, Carbon dioxide, Energy, Building material and Global warming

\section{Introduction}

The environmental issues mainly concerned with $\mathrm{CO}_{2}$ by which the overall temperature of the planet is increasing (Global warming) As a result, day to day climate is changing in unpredictable ways that is from floods and hurricanes to heat waves and droughts. Global warming is the top most concern for environmental impact on our climate and geography of the world. A lot of research has been done for how to reduce the effect of $\mathrm{CO}_{2}$ on environment. Developing countries like India where every year a huge member of concrete building is constructed where million tones of concrete used. We are concern but not understand about the impact of these building on environment because we have no data how much $\mathrm{CO}_{2}$ is released from a building from its construction phase to the end of its life.

\section{Methodology}

The Analysis focused on locally available building materials except sand and stone. A life cycle analysis is as valid as its data therefore it is crucial that data used for the completion of a life cycle analysis is acurate and current. Where comparing different life cycle analysis with one another it is crucial that equivalent data is available for both product and processes. if one product has a much higher availability of data it can not be justly compared to another product which has less detailed data. The validity of data should always be a concern with life cycle analyses, Since we are living in a global world and economy,and new processes in manufacturing methods and materials are introduced to various processes and product. The methodology followed four basic steps.

(A) Review of Industry

(B) Review of available data

(C) Development of basic inventories from available data

(D) comparing sustainability of data

The review of Industry includes general description of its. Structure identification, rates, types and grades of its product and the complete process, feed stocks and energy sources etc. and finally the quality of product with standard parameter. Various systematic step undertaken for collecting the data .

For Bricks: We took the amount of fuel used during its. production, amount of production, transport of raw materials to brick field and finally the transport of bricks to construction site. 
For Cement: The amount of clinker, and gypsum required, working hour, and electricity used for the production of cement.

For Sand: Transportation cost to construction site, and amount of fuel required for transportation and sieving.

For Steel: Electricity used for remolding and working hour for remolding.

For glass: Amount of silica glass required and electricity used for its production.

For lime coat: Amount of calcium hydroxide and carbon dioxide required for coating

For Stones: Transportation cost and amount of fuel required for transportation and crushing stones.

Apart from the above mentioned items there might be other items such us paint, water uses etc. which may be considered but the major factors like carbon emission and energy consumption have been taken into consideration only.

\section{Result and discussion}

We have taken the project and calculated the total material required for 6200 Sq. Ft. in Singrauli city and tried to specified the location and summarize all calculation that can be added into it. The area of the project- 1 and project- 2 is same but the total $\mathrm{CO}_{2}$ emission and total energy consumption is less in project- 1 due to uses of stone instead of bricks. the analysis done. shows the following facts.

From Project (1 : In construction phase stone produces 233.99 tons and cement produce 277.09 tons of $\mathrm{CO}_{2}$. The total $\mathrm{CO}_{2}$ emission per square feet in construction phase is 0.09241 tons $/ \mathrm{ft}^{2}$ and total energy consumption per square feet in construction phase is $0.90048 \mathrm{GJ} / \mathrm{ft}^{2}$.

From Project (2): In construction phase brick produces 524.47 tons, cement produces 164.79 ton of $\mathrm{CO}_{2}$, the total $\mathrm{CO}_{2}$ emission per square $\mathrm{ft}$ in construction phase is 0.118443 tons $/ \mathrm{Ft}^{2}$ and total energy consumption per square $\mathrm{ft}$ is $1.1715 \mathrm{GJ} / \mathrm{Ft}^{2}$.

Table 1- $\mathrm{CO}_{2}$ Emission and energy consumption for two Residential Building at Singrauli (Construction phase only)

\begin{tabular}{|c|c|c|c|c|c|c|c|c|c|}
\hline \multirow{2}{*}{$\begin{array}{l}\text { S. } \\
\text { N } \\
\text { o. }\end{array}$} & \multirow{2}{*}{$\begin{array}{c}\text { Item } \\
\text { description } \\
\text { (Construction } \\
\text { material) }\end{array}$} & \multirow[t]{2}{*}{$\begin{array}{l}\text { Project } \\
\text { (1) }\end{array}$} & \multirow[t]{2}{*}{$\begin{array}{l}\text { Project } \\
\text { (2) }\end{array}$} & \multicolumn{2}{|c|}{ Standard value per unit } & \multicolumn{2}{|c|}{$\mathrm{Co}_{2}$ emission(Ton) } & \multicolumn{2}{|c|}{$\begin{array}{c}\text { Energy consumption } \\
(\mathbf{G J})\end{array}$} \\
\hline & & & & $\begin{array}{c}\mathrm{Co}_{2} \\
\text { emission } \\
\text { (Ton) }\end{array}$ & $\begin{array}{c}\text { Energy } \\
\text { consumptio } \\
\mathbf{n} \\
(\mathbf{G J}) \\
\end{array}$ & $\begin{array}{l}\text { Project } \\
\text { (1) }\end{array}$ & $\begin{array}{l}\text { Project } \\
\text { (2) }\end{array}$ & $\begin{array}{l}\text { Project } \\
\text { (1) }\end{array}$ & $\begin{array}{l}\text { Project } \\
\text { (2) }\end{array}$ \\
\hline 1. & Cement (Bags) & 14283 & 8494 & 0.0194 & 0.0935 & 277.09 & 164.79 & 1335.52 & 880.05 \\
\hline 2. & Bricks (Nos.) & -- & 970440 & 0.00054 & 0.00575 & ---- & 524.47 & ------ & 5591.48 \\
\hline 3. & Stone $(\mathrm{Cft})$ & 65741 & -- & 0.00356 & 0.00483 & 233.99 & ---- & 3175.21 & ------- \\
\hline 4. & Sand (Cft) & 32814 & 20867 & 0.00138 & 0.02346 & 45.35 & 28.70 & 769.83 & 489.53 \\
\hline 5. & Rebar (Kg) & 152703 & 152703 & 0.0000624 & 0.001365 & 9.5 & 9.5 & 208.433 & 208.433 \\
\hline 6. & Glass $(\mathrm{Kg})$ & 4018 & 4018 & 0.0013 & 0.0184 & 5.22 & 5.22 & 73.93 & 73.93 \\
\hline 7. & Lime (ton) & 3.5 & 3.5 & 0.47 & 5.69 & 1.64 & 1.64 & 19.95 & 19.95 \\
\hline & & & & & Total & 572.79 & 734.32 & 5582.87 & 7263.37 \\
\hline
\end{tabular}

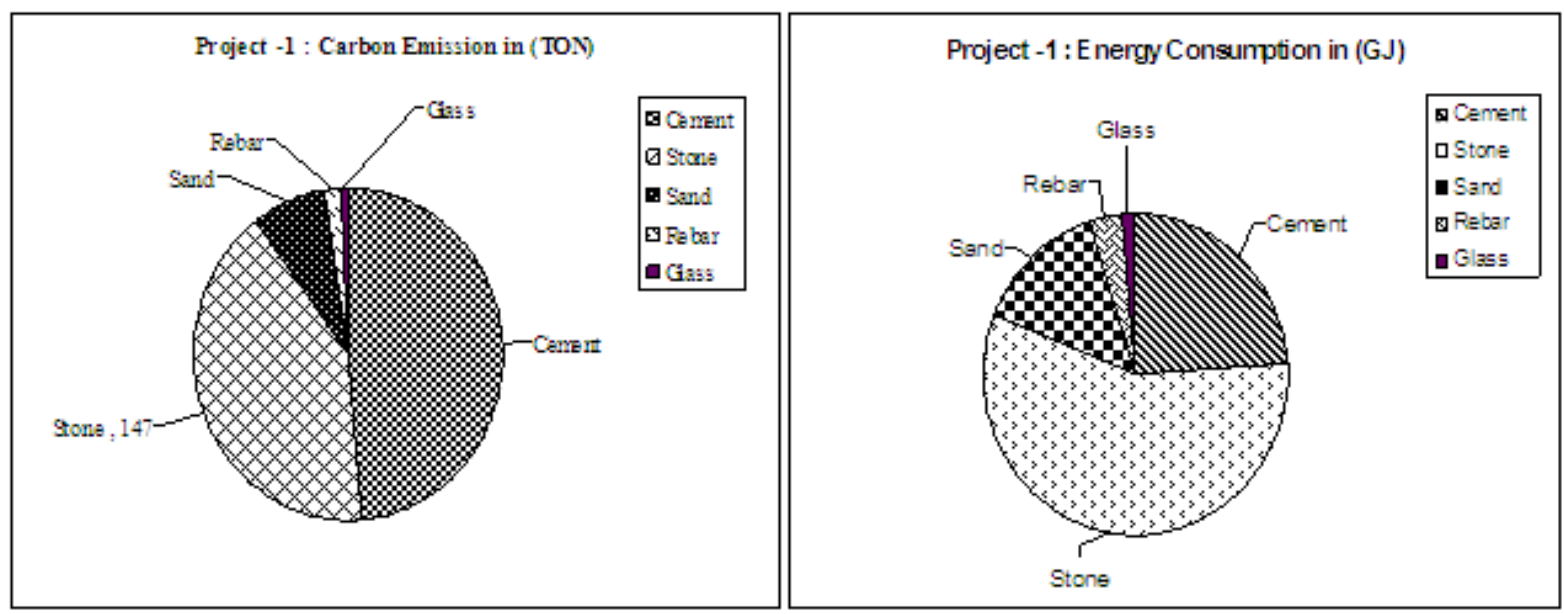




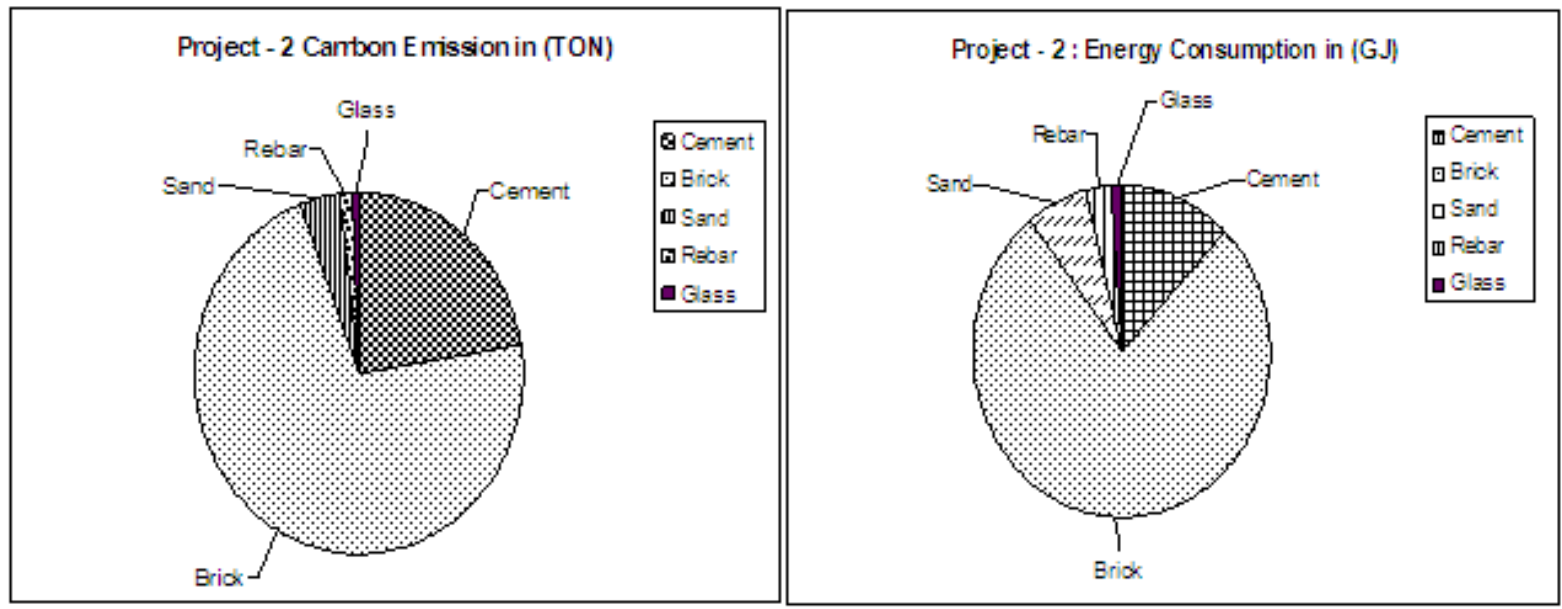

Diagram showing role of construction material in $\mathrm{Co}_{2}$ estimation and energy consumption

Hence by using brick, about 734.32 tons $\mathrm{CO}_{2}$ emitted and energy consumption is about 7263.37 GJ from a building in its construction phase on the other hand by using stones 572.79 ton of $\mathrm{CO}_{2}$ is emitted and energy consumption is about 5582.87 GJ.

Hence by using stone instead of bricks we can reduce $\mathrm{CO}_{2}$ emission about 161.53 tons (734.32-572.79) and reduction of energy consumption is about 1680.5 GJ. (7263.37-5582.87) for the same area of 6200 sq. ft. So using stone chips with the environmental point of view is beneficiary for structure.

\section{Conclusion}

We have much concern about the impact of industry on environment. A large number of concrete building are constructed in the world every year and month. Impact of emission of $\mathrm{CO}_{2}$ is threatened on environment but we are not concern because we have no data how much $\mathrm{CO}_{2}$ is released from a building from its construction phase to the end of its life. the use of a more than thousand million M.T. concrete of which about 150 million M.T. wate and about 250 million M.T. Cement and 600 million M.T. aggregate is used in India. The total aggregate used in the world is more than 9 (Nine) billion tones. So by using energy saving material we can reduce $\mathrm{CO}_{2}$ emission substantially. Hence for the reduction in $\mathrm{CO}_{2}$ emission we have to work more to improve the bricks production method and natural gas or should use stone chips instead of bricks

This analysis will encourage us to do more and more work for reducing the environmental impact of $\mathrm{CO}_{2}$ to meet out well the environmental issues to keep our environmental safe and healthy.

\section{References}

[1]. Chalaruk, C., Control of aquaculture wastes by bacterial decomposition. M.Sc. thesis, Institute of Aquaculture, Stirling University, 91 pp. (1988)

[2]. DEFOE, D., The fortunes and the misfortunes of the famous Moll Flanders. (Online). Champaign, Illinois: Project Gutenberg Available at: http://www.promo.net/cgipromo/pg/t9.cgi?entry=370\&full, (1995)

[3]. Schell, J. A., The fate of the Earth. London : Chapman \& Hall, 231,p. (1996)

[4]. Chung, K.T., Stevens, S. E. and Bultron, G., Degradation of azo dyes by environmental microorganism and helminthes. Environ. Toxicol. Chem., 12 (2): 121-132, (1993)

[5]. Coyle, M., Attacking the cult-historicists. Renaissance Forum.(online). Available at: http://www.hull.ac.uk/English/renforum/v1no1/coyle.htm (Accessed 18 August 2014), (1996)

[6]. Wright, R., Rosenfeld, R. and . Jacobs, B. A., Snitching and the code of the street. The British Journal of Criminology (online). 43(2): 291-309. Available via: Ingenta, (2003)

[7]. Alam, Md. Shahrior, Ahmad, Syed Ishitaq, Analysis of Life Cycle Environmental Impact For Residential Building in Bangladesh, International Journal of Technology Enhancements and Emerging Engineering Research, vol. 2, Issue 1, pp. 1-4, (2013) 